\title{
Data Integration Reveals the Potential Biomarkers of Circulating MicroRNAs in Osteoarthritis
}

\author{
Thuan Duc Lao $\mathbb{1}$ and Thuy Ai Huyen Le * \\ Faculty of Biotechnology, Ho Chi Minh City Open University, Ho Chi Minh City 700000, Vietnam; \\ thuan.ld@ou.edu.vn \\ * Correspondence: thuy.lha@ou.edu.vn
}

check for updates

Citation: Lao, T.D.; Le, T.A.H. Data Integration Reveals the Potential

Biomarkers of Circulating MicroRNAs in Osteoarthritis. Diagnostics 2021, 11, 412. https://doi.org/10.3390/ diagnostics11030412

Academic Editor: Sten Rasmussen

Received: 12 January 2021

Accepted: 18 February 2021

Published: 28 February 2021

Publisher's Note: MDPI stays neutral with regard to jurisdictional claims in published maps and institutional affiliations.

Copyright: (C) 2021 by the authors. Licensee MDPI, Basel, Switzerland. This article is an open access article distributed under the terms and conditions of the Creative Commons Attribution (CC BY) license (https:// creativecommons.org/licenses/by/ $4.0 /)$.

\begin{abstract}
The abnormal expression of circulating miRNAs (c-miRNAs) has become an emerging field in the development of miRNAs-based diagnostic and therapeutic tools for human diseases, including osteoarthritis (OA). OA is the most common form of arthritis leading to disability and a major socioeconomic burden. The abnormal expression of miRNAs plays important roles in the pathogenesis of OA. Unraveling the role of miRNAs in the pathogenesis of OA will throw light on the potential for the development of miRNAs-based diagnostic and therapeutic tools for OA. This article reviews and highlights recent advances in the study of miRNAs in OA, with specific demonstration of the functions of miRNA, especially c-miRNA, in OA pathogenesis as well as its potential implication in the treatment of OA. Based on a systematic literature search using online databases, we figured out the following main points: (1) the integrative systematic review of c-mRNAs and its target genes related to OA pathogenesis; (2) the potential use of c-miRNAs for OA diagnosis purposes as potential biomarkers; and (3) for therapeutic purposes, and we also highlight certain remedies that regulate microRNA expression based on its target genes.
\end{abstract}

Keywords: osteoarthritis; circulating miRNAs; miRNAs-based diagnosis; miRNAs-based therapeutic

\section{Introduction}

Osteoarthritis (OA) is the most common degenerative joint disease and the leading cause of pain and disability, affecting more than $25 \%$ of the adult population [1-3]. Worldwide, $10 \%$ of men and $18 \%$ of women aged 60 years and above are diagnosed with OA [4]. In addition, $\mathrm{OA}$ is considered a tremendous individual and socioeconomic burden as a result of loss of productivity and increased medical costs, leading to reduced quality of life $[5,6]$. Both exogenous and endogenous factors have been identified as etiological factors of OA $[7,8]$ (Table 1).

The primary clinical symptoms are joint pain (history of joint pain), stiffness, locomotor restriction, muscle weakness, and poor balance, which guide the diagnosis. To date, radiography remains the gold standard for diagnosing OA [9]. However, the gold standard diagnosis has limitations when assessing and monitoring the early stage of OA [1,9]. Other than joint surgery-based treatment, there is no cure for OA, and most treatments focus on the relief of symptoms such as pain. However, side effects from pain medications, such as dizziness, which contributes to falls, have been reported during therapy. Therefore, improved identification of potential biomarkers that promote OA progression as well as therapeutic strategies are not only essential for the development of new diagnosis strategies, but also for promising treatment outcomes. 
Table 1. Endogenous and exogenous risk factors of osteoarthritis (OA).

\begin{tabular}{|c|c|}
\hline Endogenous Factors & Comments \\
\hline Age & $\begin{array}{l}\text { Increasing incidence rate in younger adults. Over half of people } \\
\text { diagnosed are under } 65 \text { years of age }[10,11] .\end{array}$ \\
\hline Gender & $\begin{array}{c}\text { OA is more common in women than men, particularly after } \\
\text { menopausal age }[12,13] .\end{array}$ \\
\hline Ethnicity & $\begin{array}{c}\text { OA is more common in African-Americans compared to other ethnic } \\
\text { groups [14]. }\end{array}$ \\
\hline Genetics, Epigenetics & $\begin{array}{l}\text { Genetic loci, multigene interaction, family heredity, methylation, } \\
\text { histone modification, microRNA }[7,8,15-18] \text {. }\end{array}$ \\
\hline Exogenous Factors & Comments \\
\hline Knee events & Injury, joint surgery, knee pain, trauma or repeated loading $[7,8,19]$. \\
\hline Obesity & $\begin{array}{c}\mathrm{BMI}>30 \mathrm{~kg} / \mathrm{m}^{2} \text { were } 6.8 \text { times more likely to develop knee OA than } \\
\text { normal-weight controls [20]. }\end{array}$ \\
\hline Lifestyle factors & Tobacco, alcohol assumption $[21,22]$. \\
\hline Nutrition & $\begin{array}{l}\text { Metabolic disease, such as lipid and cholesterol profiles, adequate } \\
\text { vitamin levels, etc., essentially contribute to OA }[23,24] \text {. }\end{array}$ \\
\hline Occupation, sports & $\begin{array}{c}\text { The link between occupational activities, including kneeling, } \\
\text { squatting, lifting, climbing, heavy stand working, heavy physical } \\
\text { load work or combinations thereof, and OA has been } \\
\text { reported [25-27]. Thus, many occupations have been reported to be } \\
\text { linked to OA, such as floor layers, miners, dockers, carpenters, } \\
\text { firefighting, mining asphalt, plumbers, bricklayers, sports at elite } \\
\text { levels, etc. [28,29]. }\end{array}$ \\
\hline
\end{tabular}

Research programs related to the development of early diagnosis tools and monitoring the progression of OA based on biomarkers have gained considerable attention in recent years. In a recent study, $4191 \mathrm{OA}$ patients $(41.88 \%$ male and $58.12 \%$ female) were recruited to identify potentially clinically useful biomarkers of OA [30]. The data showed that of the biomarkers, including serum $\mathrm{C} 1, \mathrm{C} 2$, serum $\mathrm{C} 2 \mathrm{C}$, serum CPII, serum PIIANP, serum Coll21 NO2, serum CS846, serum MMP3, serum CTXI, serum COMP, serum HA, serum NTXI, urine CTXII, urine C1, C2, urine C2C, urine NTXI, urine CTXI alpha, urine CTXI beta, urine Coll21 NO2, and urine creatinine, only four, namely, serum Coll21 NO2, serum CS846, serum COMP, and urine CTXII, were reported to be consistently associated with OA, thus providing promising potential biomarkers of OA [30]. Among these four potential biomarkers, the urine CTXII was identified as the biomarker with the strongest and most significant association with features of OA [30]. Based on further investigation, these four biomarkers may be clinically useful surrogates that can be used for the development of biomarkers of $\mathrm{OA}$ in the near future. Molecules that exist in joint fluid have also attracted interest in the investigation of biomarkers for OA. For example, 159 OA patients, a total of 138 patients returned for follow-up 3 years later to assess progression of knee OA, and the study found that the NLRP3 gene was activated by uric acid. When activated, this leads to the production of IL-18 and IL-1 $\beta$. Synovial fluid uric acid and IL-18 were strongly and positively associated with OA severity, and synovial fluid IL-1 $\beta$ was associated with OA severity. Additionally, synovial fluid IL-18 was identified to be associated with a 3-year change in OA severity. These results strongly support the potential involvement of the innate immune system in OA pathophysiology. Therefore, synovial fluid uric acid is a marker of knee OA severity [31]. Even though there are currently no biomarkers approved by the FDA for the diagnosis and monitoring of OA due to limited specificity and sensitivity, such advanced research in the OA biomarker field is still progressing steadily $[30,32]$. The majority of nucleic acid-based molecules, such as circulating miRNAs (c-miRNAs), exist in different biological fluid types, such as blood, serum, plasma, saliva, tears, urine, milk, follicular fluid, semen, etc., and they have shown great potential for application of circulating biomarkers for early diagnosis since they can be secreted into circulation and 
are stable. Several studies have indicated that the selective expression of c-miRNAs plays a key role in the progression of OA. In this review, we focus on the compilation of studies regarding the expression of c-miRNAs in OA. These abnormal expressions of c-miRNAs could be used as potential biomarkers to improve current diagnostic practices performed in the clinic to detect and monitor OA.

\section{Brief Introduction to miRNAs and c-miRNAs}

Epigenetic modification, including DNA methylation, histone modification and microRNAs (miRNAs), refers to the heritable changes in gene expression without any changes in DNA sequence [33]. Since the discovery of miRNA, lin-4, in 1913 by Ambros and Ruvkun in Caenorhabditis elegans, miRNAs have attracted attention as potential biomarkers of several human diseases, including OA. Mature miRNAs are single-strand non-coding RNA with lengths of 19-25 nucleotides [1,34]. The biogenesis of miRNA is classified into two categories: (1) the canonical pathway, and (2) the non-canonical pathway [35]. miRNAs function via base-pairing with their target gene to modulate the target gene expression, which plays various roles in diverse processes of living, including cell proliferation, differentiation, metabolism, stress response and apoptosis [36]. Compared with mRNA, an unexpected characteristic of miRNA is the stability of the short sequences that are detected in the cellular microenvironment [37]. Recently, a handful of miRNAs, known as c-miRNAs or extracellular miRNAs, were detected in the outside environment of the cell (extracellular environment), including blood, serum or plasma [1,37]. Additionally, not only were they detected in blood, serum or plasma, c-miRNAs were also detected in different biological fluid types, such as saliva, tears, urine, milk, follicular fluid, semen, etc. [1,37,38]. Accumulating evidence has shown that c-miRNAs are resistant to degradation by ribonuclease activities in plasma or any other biological fluids, suggesting that they are protected in a specific manner, that is, packing in small membrane vesicles, such as exosomes, microvesicles, apoptotic bodies, RNA-binding proteins (AGO-2), nucleophosmin I, and lipoprotein complexes (such as high-density lipoprotein (HDL) $[35,37,39,40]$. In addition to the property of resistance to RNase activity, one of the key molecular characteristics of c-miRNAs is high stability in extreme physiological conditions, such as high or low $\mathrm{pH}$, and different variations, such as boiling and multiple freeze-thaw cycles $[39,41]$. Aberrant expression of miRNAs, as well as c-miRNAs, has been linked to many human diseases, such as inflammatory diseases $[39,42]$, cancers [43-45], immune-related diseases [46], neurodegenerative diseases [47], etc., including OA. However, data concerning their detection could be controversial since miRNAs, as well as c-miRNAs, are not specific to certain diseases; however, they may add to the procedure of diagnosis and therapeutic approaches in combination with other markers, such as their downstream target genes, to build a specific signature for a certain disease. It is noted that more than $50 \%$ of all genes in the human genome are reported to be the target genes of miRNAs/c-miRNAs, thus resulting in the regulation of manifold metabolic and regulatory pathways such that the integrative network between miRNA/c-miRNAs and its target genes becomes more and more possible [48,49]. Hence, the abnormal expression profiles of miRNAs could be applied in the management of certain human diseases.

Remarkable studies have been published about c-miRNAs' dysregulated expression correlated with the pathogenesis of OA, such as osteoarthritic cartilage apoptosis, autophagy, chondrogenesis and cartilage homeostasis, matrix metalloproteinases and aggrecanases, inflammation, etc. In this review, we summarize the studies that have revealed a link between c-miRNA and OA by shedding light on c-miRNAs and their possible functions, in addition to commenting on their potential as noninvasive biomarkers of OA.

\section{3. c-miRNA Signature as Potential Biomarker for OA Diagnosis}

In order to understand the extent to which c-miRNAs are involved in the processes of pathogenesis, we analyzed the results of many recent studies focused on how c-miRNAs regulate those events that are germane to OA pathophysiology. A number of c-miRNAs have been found to be involved in the pathogenesis of OA (Table 2). 
Table 2. The dysregulation of circulating miRNAs (c-miRNAs) in the pathogenesis of OA.

\begin{tabular}{|c|c|c|}
\hline References & c-miRNAs & Sources \\
\hline [1] & $\begin{array}{c}\operatorname{miR}-122 \uparrow, \text { miR-25 } \downarrow \text {, miR-28-3p } \downarrow, \text { miR-93 } \downarrow, \text { miR-140 } \downarrow, \operatorname{miR}-191 \downarrow, \text { miR-342-3p } \downarrow, \\
\text { miR-146b } \downarrow, \text { miR-454 } \downarrow \text {, miR-885-5p } \uparrow, \text { miR-let-7b } \downarrow \text {, miR-let-7e } \downarrow\end{array}$ & Serum \\
\hline$[50]$ & $\operatorname{miR}-146 \mathrm{a} \uparrow, \mathrm{miR}-155 \uparrow$ & Peripheral blood \\
\hline [51] & $\operatorname{miR}-132 \downarrow, \operatorname{miR}-146 \mathrm{a} \uparrow, \mathrm{miR}-155 \uparrow, \mathrm{miR}-181 \uparrow, \mathrm{miR}-223 \uparrow$ & Serum \\
\hline [52] & $\operatorname{miR}-146 a-5 p \uparrow$ & Serum \\
\hline [53] & miR-146a-5p $\uparrow, \operatorname{miR}-186-5 p \uparrow$ & Serum \\
\hline [54] & $\begin{array}{l}\operatorname{miR}-16 \uparrow, \operatorname{miR}-20 \mathrm{~b} \uparrow, \operatorname{miR}-19 \mathrm{c} \uparrow, \operatorname{miR}-30 \mathrm{~b} \uparrow, \operatorname{miR}-93 \uparrow, \operatorname{miR}-126 \uparrow, \operatorname{miR}-184 \uparrow, \operatorname{miR}-186 \uparrow, \\
\operatorname{miR}-195 \uparrow, \operatorname{miR}-345 \uparrow, \operatorname{miR}-885-5 \mathrm{p} \uparrow\end{array}$ & Plasma \\
\hline$[55] *$ & $\begin{array}{c}\operatorname{miR}-23 a-3 p \uparrow, \operatorname{miR}-24-3 p \uparrow, \operatorname{miR}-27 a-5 p \downarrow, \operatorname{miR}-27 b-3 p \uparrow, \operatorname{miR}-29 c-3 p \uparrow, \operatorname{miR}-34 a-5 p \uparrow, \\
\text { miR-329 } \downarrow \text {, miR-655 } \downarrow \text {, miR-708-3p } \downarrow, \operatorname{miR}-934 \downarrow \text { and miR-186-5p } \uparrow \\
\text { miR-27a-3p, miR-101-5p, miR-378-5p only detected in the late stage of OA. }\end{array}$ & Synovium \\
\hline [56] & miR-140-3p $\downarrow$, miR-33b-3p $\downarrow$, miR-671-3p $\downarrow$ & Serum \\
\hline [57] & $\operatorname{miR}-132 \downarrow$ & Synovium, plasma \\
\hline [58] & $\begin{aligned} & \operatorname{miR}-122-5 \mathrm{p} \uparrow, \operatorname{miR}-92 \mathrm{a}-3 \mathrm{p} \uparrow, \\
& \mathrm{miR}-19 \mathrm{~b}-3 \mathrm{p} \uparrow, \mathrm{miR}-486-5 \mathrm{p} \uparrow, \mathrm{miR}-877-5 \mathrm{p} \downarrow, \mathrm{miR}-1180-3 \mathrm{p} \downarrow \\
&\end{aligned}$ & Blood \\
\hline [59] & $\operatorname{miR}-120 \uparrow$ & Synovium \\
\hline
\end{tabular}

Note: $\uparrow$ Upregulated, $\downarrow$ Downregulated; * c-miRNAs' expressions were compared in the late stage of OA vs early stage of OA.

Further, many c-miRNAs have been found to be overexpressed in OA, including miR146a, miR-155, miR-181, miR-223, miR-16, miR-20, miR-30, miR-126, miR-184, miR-186, miR-195, miR-345, miR-885, miR-122, miR-23a-3p, miR-24-3p, miR-27b-3p, miR-29c-3p, miR-34a-5p, miR-92-3p, and miR-486-5p (Table 2). One of the most studied overexpressed c-miRNAs is miR-146a [50-53].

As described, miRNAs are not specific to certain diseases; miR-146a has also been reported to be linked to many human diseases, such as Type II diabetes [60], systemic lupus erythematosus $[61,62]$, cancers $[63,64]$, etc. The complex target networks pose a significant challenge to establishing a specific signature for a certain disease. Higher expression of miR-146a and its integrative network have been reported to be correlated with the pathogenesis of OA. miR-146a-5p was significantly overexpressed in OA patients in samples of cartilage $(p=0.006)$ and serum $(p=0.002)$, which were analyzed by qPCR for 28 OA patients compared with those of two healthy controls [52]. The expression levels of miR-146a-5p in the serum were positively correlated with those of the cartilage (Pearson correlation coefficient, $\mathrm{R}=0.32 ; p=0.002$ ) [52]. With a next-generation sequencing approach and qPCR, Rousseau et al. concluded that serum miR-146a-5p was significantly overexpressed in a group of OA patients compared with the controls [53]. Therefore, they suggested that miR-146a-5p serum level could serve as a non-invasive clinical utility biomarker for OA management. It has been determined that the function of miR-146a is linked to cartilage degradation, synovial inflammation, neoangiogenesis, and osteoclastogenesis [52]. To support the understanding of the OA mechanism, the target genes of $\mathrm{miR}-146 \mathrm{a}$ have been determined for OA pathophysiology. The target genes of miR-146a, including Bcl-2, TRAF6, IRAK1, VEGF, Smad4, and TGF- $\beta$, have been identified in previous studies [50-53,65-69]. Autophagy was reported to be induced by hypoxia via miR-146a, and Bcl-2 [65]. Moreover, miR-146a promotes chondrocyte autophagy by inhibiting Bcl-2, an autophagy inhibitor [65]. The inhibition of Bcl-2 by hypoxia-induced miR-146a has been found to promote chondrocyte autophagy through the pathway of TRAF6/IRAK1 [66]. Furthermore, a study reported that miR-146a was increased by mechanical pressure injury, and its upregulation induced the apoptosis of human chondrocytes via inhibition of Smad4 in the cartilage by harboring a miR-146a binding sequence in the $3^{\prime}$-UTR of its mRNA [67]. The function of Smad4 in the chondrocytes is to serve as the mediator of the upregulation of 
miR-146a-induced VEGF subjected to mechanical pressure injury. The results of the study indicated that miR-146a plays a key role in the apoptosis of human chondrocyte, thereby contributing to the pathogenesis of OA by increasing the levels of VEGF and damaging the transforming growth factor (TGF)- $\beta$ signaling pathway through the targeted inhibition of Smad4 in the cartilage [67]. The rupture of cartilage homeostasis results in the induction of phenotypic modifications of chondrocytes, leading to cartilage damage and pathogenesis of OA [68]. Cartilage homeostasis has been reported to be regulated by miR-146a through the suppression of cartilage matrix-associated gene expression, including Camk2d and Ppp3r2 [69]. miR-146a inhibitor-based treatment of surgically-induced OA mice was shown to significantly alleviate the destruction of articular cartilage via targeting of Camk2d and Ppp3r2 [69]. (Figure 1).

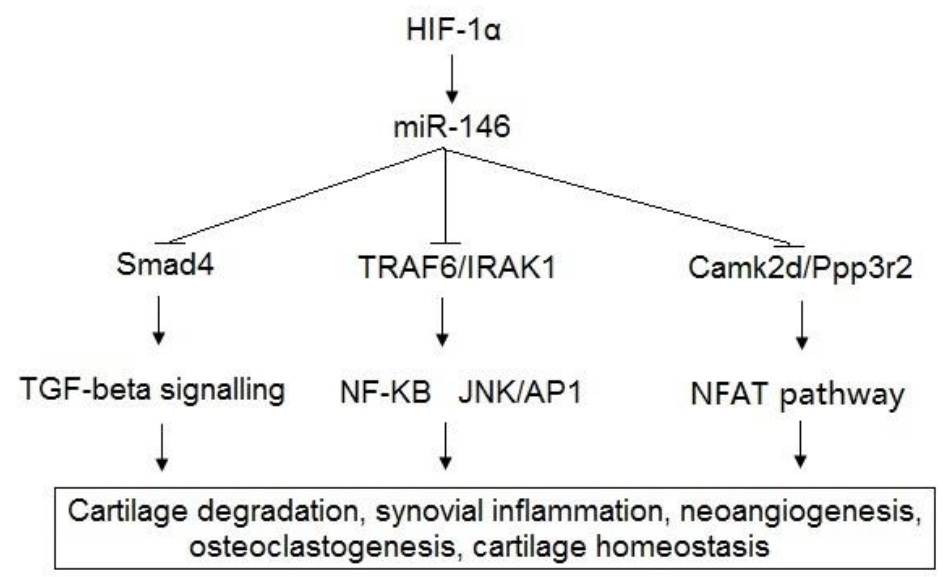

Figure 1. Schematic representation of miR-146 and its target genes related to pathogenesis of OA.

Other miRNAs were also reported to be significantly correlated with the pathogenesis of OA. The levels of 380 plasma miRNAs in patients with OA and healthy controls were compared. The results indicated there were 12 overexpressed detectable miRNAs, including miR-16, miR-20b, miR-29c, miR-30b, miR-93, miR-126, miR-146a, miR-184, miR-186, miR195 , miR-345, and miR-885-5p, that were altered in the OA and could be released into the plasma [54]. Moreover, in their report, they indicated that, among them, the expression of 8 miRNAs, including miR-29c, miR-93, miR-126, miR-184, miR-186, miR-195, miR-345 and miR-885, was confirmed as the high expression of c-miRNAs, presenting a three- to fourfold change in patients with OA based on qPCR analysis [54]. The putative target mRNA genes of these miRNAs, such as FGFRR1, HDAC4, FGF2, VEGFA, IGFIR, ADAMTS5, TIMP2, and WISP1, were differentially expressed in OA. All the targets are important in OA because they take part in diverse signaling pathways including chondrocyte maintenance, osteocyte modulation, and chondrocyte inflammation [54]. Furthermore, six miRNAs, including miR-23a-3p, miR-24-3p, miR-27b-3p, miR-29c-3p, miR-34a-5p and miR-186- 5p, were significantly upregulated in late-stage OA synovial fluid compared with early-stage OA synovial fluid [55]. Among them, miR-29c and miR-186 have been reported to be overexpressed in the plasma of early-stage OA synovial fluid compared with healthy controls [55]. Overall, the identification of such patterns of c-miRNAs in body fluids suggests that the significant difference between late-stage and early-stage OA may help in examining the outcomes of disease to develop the diagnosis as well as the therapeutics of OA in the future. Mounting evidence suggests that miR-186 over-expression is involved in the pathogenesis of OA; however, controversies regarding miR-186 expression in OA still exist. In other study, which aimed to study the mechanism of miR-186 in OA, the expression levels of miR-186 were measured in the cell in vivo using q-PCR. Their results indicated that miR-186 was remarkably decreased in comparison with the control group. Interestingly, miR-186 was shown to increase chondrocyte survival, facilitate cell cycle entry in OA chondrocytes, and inhibit the PI3K-AKT pathway via SPP1-inhibited chondrocyte 
apoptosis in mice with OA. Notwithstanding these controversies, these results have opened up an approach to early diagnosis and prognosis of OA [70].

The downregulation of miRNAs, including miR-132, miR-25, miR-28, miR-140, miR191, miR-342, miR-454, miR-let-7b, miR-let-7a, miR-27a, miR-329, miR-708, miR-934, miR877, miR-1180, miR-320b, and miR-663a, has been identified in the progression of OA (Table 2). Another miRNA that has been studied in OA is miR-140. Its expression was decreased in osteoarthritic cartilage compared with healthy cartilage $[1,56,71]$. In other study, serum analysis was performed on 12 primary OA patients, compared with 12 healthy individuals, and the results indicated that miR-140 expression levels were consistently downregulated in articular cartilage of OA patients [56]. In their report, InsR and IGFR were identified as the common targets of miR-140, which are both involved in the regulation of metabolic processes contributing to the pathophysiology of OA [56]. Additionally, ADAMTS5, MMP-13, IGFBP5, and RALA, which play important roles in mediating the degradation of cartilage matrix, modulating the availability of IGF-1 in joint and regulating cartilage matrix development, have been identified as targets of miR-140 [71-73]. Transgenic mice miR-140-/- were designed that showed age-related OA-like changes characterized by proteoglycan loss and fibrillation of articular cartilage [71]. Furthermore, the transgenic mice with overexpression of miR-140 were reported to be resistant to antigen-induced arthritis via the regulation of ADAMTS5, a major cartilage matrixdegrading protease in OA. Their findings demonstrated that miR-140 was required for the development of skeletal as well as cartilage homeostasis, and protected against OA-like pathophysiology via the regulation of ADAMTS5 [71].

Furthermore, several targets of miRNAs in the progression of $\mathrm{OA}$, which play various roles in apoptosis, autophagy, chondrogenesis and cartilage homeostasis, matrix metalloproteinases and aggrecanases, inflammation, etc., have also been identified in numerous studies $[1,34,53,74,75]$. Our literature search identified a wide range of target genes of miRNAs that have been indicated to be associated with OA progression, as summarized in Table 3.

Table 3. Experimentally verified target genes of c-miRNAs involving OA.

\begin{tabular}{|c|c|c|c|}
\hline References & c-miRNAs & Target Genes & Function \\
\hline$[50-53,65-69]$ & miR-146a & $\begin{array}{l}\text { Bcl-2, TRAF6, IRAK1, VEGF, Smad4, TGF- } \beta \text {, } \\
\text { Camk2d, Ppp3r2 }\end{array}$ & $\begin{array}{c}\text { Cartilage degradation, synovial inflammation, } \\
\text { neoangiogenesis, osteoclastogenesis, } \\
\text { cartilage homeostasis. }\end{array}$ \\
\hline$[37,41,76]$ & miR-155 & ULK1, MAP1LC3, ATG14, SHIP1 & Autophagy, inflammation \\
\hline [77] & miR-181 & PTEN & Apoptosis \\
\hline [78] & miR-16 & Smad3 & Chondrocyte growth, differentiation \\
\hline$[79,80]$ & miR-30b & ERG, BECN1 & Chondrocyte differentiation, autophagy \\
\hline [81] & miR-126 & Bcl-2 & Inflammation \\
\hline [70] & miR-186 & SPP1 & Chondrocyte apoptosis \\
\hline$[64,82]$ & miR-195 & HIF- $1 \alpha$, REG $\gamma$ & Chondrocyte apoptosis, inflammation \\
\hline$[83,84]$ & $\operatorname{miR}-23 a$ & Smad3, RUNX2 & Chondrocyte growth, cartilage homeostasis \\
\hline [85] & $\operatorname{miR}-24$ & $\mathrm{p} 16^{\mathrm{INK} 4 \alpha}$ & $\begin{array}{l}\text { Reduces production of the two matrix } \\
\text { remodeling enzymes }\end{array}$ \\
\hline$[86,87]$ & $\operatorname{miR}-27 b$ & MMP-13, CBFB & Matrix degradation, chondrocyte differentiation \\
\hline$[88,89]$ & $\mathrm{miR}-34 \mathrm{a}$ & Col2 $\alpha 1$, iNOS, TGIF2 & Chondrocyte apoptosis \\
\hline$[90]$ & $\mathrm{miR}-92 \mathrm{a}$ & HADC2 & Cartilage development and homeostasis \\
\hline$[91,92]$ & $\operatorname{miR}-19 b$ & EZH2, LncRNA H19 & Chondrocyte apoptosis, ECM degradation \\
\hline [93] & $\mathrm{miR}-486$ & Smad2 & Chondrocyte growth \\
\hline$[56,71-73]$ & $\operatorname{miR}-140$ & $\begin{array}{l}\text { InsR, IGFR, ADAMTS5, MMP-13, IGFBP5, } \\
\text { RALA }\end{array}$ & $\begin{array}{l}\text { Metabolic processes, cartilage homeostasis } \\
\text { and chondrogenesis. }\end{array}$ \\
\hline$[94,95]$ & miR-25 & COX2 & Inflammation \\
\hline [96] & miR-107 & TRAF3 & Chondrocyte apoptosis, autophagy \\
\hline
\end{tabular}


The discussion above shows that many previous studies have highlighted the possible application of c-miRNAs as well as miRNAs as novel biomarkers of OA. Hence, studying the dysregulation of miRNA and its integrative network provides the hope that, in the near future, miRNAs could serve as biomarkers of OA.

\section{Therapeutic Potential of c-miRNAs in OA}

Currently, miRNA-based therapeutics have been developed for the treatment of a variety of human diseases. Three miRNA-based therapeutic approaches have been suggested: (1) miRNA sponge-expression vector, (2) small molecule inhibitor, and (3) antisense oligonucleotides (ASO) [97]. Even though miRNA-based therapeutic drugs have not been commercially available, many miRNA-based drugs are in the process of development by numerous pharmaceutical and biotech companies. Some of these include RG-101 (targeted miRNA: miR-122; Phase 2; Company: Regulus therapeutics, regulusrx.com) for HCV therapy; MRG-106 (targeted miRNA: miR-155; Phase 1 and Phase 2; Company: MiRagen Therapeutics, miragentherapeutics.com) for lymphoma and leukemia therapy; and Mesomir (targeted miRNA: miR-16; Phase 2; Company: ENGeneIC; Phase 2, engeneic.com) for mesothelioma therapy.

miRNAs, as well as c-miRNAs, have been proposed as potential therapeutic candidates to ameliorate human diseases, including OA, through addressing the signature profile of dysregulation of miRNAs. If an upregulated miRNA contributes to the pathogenesis of OA, the inhibition therapies of that miRNA could be used to block it [98]. However, clinical success in the regulation of these molecules has been inadequate so far. An example of miRNA-target therapy of OA is the inhibition of miR-34a by the LNA-ASO method in mice [99]. In a study, the expression level of miR-34a-5p was reported to be significantly increased in human plasma, cartilage and synovium of late-stage OA patients and in the cartilage and synovium of mice subjected to surgical destabilization of the medial meniscus (DMM). Using an in vivo-grade, five-microgram of miR-34a-5p LNA-ASO was injected into the knee joints of mice at two, four and six weeks post DMM surgery. The results indicate that miR-34a-5p LNA-ASO prevented the degeneration of articular cartilage by the reduction of proteoglycan loss, chondrocyte loss, cartilage fibrillation, as well as the reduction of CASPASE-3, PARP p85 and MMP-13 expression, compared with controlinjected mice [99]. Thus, the pre-clinical data from the study confirmed that miR-34a-5p LNA-ASO-based therapy has the potential to protect against DMM-induced cartilage damage [99]. Endisha et al. demonstrated that the injection of miR-34a-5p ASO imparts cartilage-protective effects in a mice model [99]. In a previous study reported that the injection of anti-miR-34a encoded lentiviral vector ameliorated the progression of OA by the regulation of the SIRT1/p53 signaling pathway [100]. Furthermore, it is possible that targeting the gene network of miRNAs can lead to positive effects in the treatment of OA. The axis of miR-122/SIRT1 regulated the chondrocyte extracellular matrix degradation, thus, providing new insights into the treatment of OA [101]. A study focused on the use of resveratrol (trans-3-4-5-trihydroxystilbene), which is targeted at SIRT1, to prevent the progression of OA [102]. In the study, the administration of resveratrol significantly induced the activation of SIRT1, thereby silencing the expression of HIF-2 $\alpha$ in mouse OA cartilage, preventing the progression of OA [102]. Therefore, it emphasizes the mechanisms underlying the activities of alternative remedies and their role in regulating miRNAs linked to OA progression, leading to the development of the miRNA-based therapy for OA.

\section{Conclusions}

In summary, as described in the article, multiple studies have demonstrated that the abnormal expression of miRNAs potentially plays an important role in the pathogenesis of OA by regulating many diverse processes, including cartilage degradation, synovial inflammation, neoangiogenesis, osteoclastogenesis, and cartilage homeostasis. Also, specific dysregulated miRNAs, c-miRNAs, could be released into body fluids, such as plasma, peripheral blood and synovial fluid, and these c-miRNAs are potential biomarkers of 
OA. On the other hand, the development of miRNAs-based diagnostic and therapeutic tools for human diseases, including OA, is definitely a long process. It is noted that the increasing evidence of miRNAs' involvement in OA signals is the beginning of this long process. Therefore, it is necessary to perform validation analysis for the development of miRNAs-based therapeutics for OA.

Author Contributions: All authors contributed to the design and conception of the study. T.D.L.: writing original draft; T.A.H.L.: review and editing the manuscript. All authors have read and agreed to the published version of the manuscript.

Funding: This research received funding sponsored by the Ministry of Education and Training, Vietnam and Ho Chi Minh City Open University, HCMC, Vietnam under the grant number B2019MBS-11.

Institutional Review Board Statement: Ethical review and approval were waived for this study, as this study is a review article.

Informed Consent Statement: Not applicable.

Data Availability Statement: Not applicable.

Acknowledgments: We wish to express our thanks to the research project sponsored by the Ministry of Education and Training, Vietnam, and Ho Chi Minh City Open University, HCMC, Vietnam.

Conflicts of Interest: The authors declare no conflict of interest.

\section{Abbreviations}

$\begin{array}{ll}\text { ADAMTS5 } & \text { A disintegrin-like and metalloproteinase with thrombospondin-1 motifs } 5 \\ \text { AGO } & \text { Argonaute protein } \\ \text { AKT } & \text { Serine/threonine-specific protein kinase } \\ \text { ATG14 } & \text { Autophagy related } 14 \\ \text { Bcl-2 } & \text { B-cell lymphoma } 2 \\ \text { BECN1 } & \text { Beclin 1 } \\ \text { BMI } & \text { Body mass index } \\ \text { C1, C2, C2C } & \text { Types I and II collagen marker degradation markers } \\ \text { Camk2d } & \text { Calcium/calmodulin-dependent protein kinase type II delta } \\ \text { CASPASE-3 } & \text { Cysteine-dependent aspartate-directed proteases 3 } \\ \text { CBFB } & \text { Core-binding factor subunit beta } \\ \text { c-miRNA } & \text { Circulating microRNA } \\ \text { Col2 } \alpha 1 & \text { The type II collagen gene } \\ \text { Coll2-1 NO2 } & \text { The nitrated form of } \alpha \text {-helical region of type II collagen } \\ \text { COMP } & \text { Oligomeric matrix protein } \\ \text { COX2 } & \text { Prostaglandin-endoperoxide synthase 2 } \\ \text { CPII } & \text { C-propeptide of type II collagen } \\ \text { CS846 } & \text { Chondroitin sulphate } 846 \\ \text { CTXI } & \text { C-terminal cross-linked telopeptide of type I collagen } \\ \text { CTXI alpha and CTXI beta } & \text { Alpha and beta isomerised versions of the CTXI } \\ \text { CTXII } & \text { C-terminal crosslinked telopeptide of type II collagen } \\ \text { DMM } & \text { Medical meniscus } \\ \text { ERG } & \text { Erythroblastosis virus E26 oncogene homolog-related gene } \\ \text { EZH2 } & \text { Enhancer of zeste homolog 2 } \\ \text { FGF2 } & \text { Fibroblast growth factor 2 } \\ \text { FGFR } & \text { Fibroblast growth factor receptor } \\ \text { HA } & \text { Hyaluronic acid } \\ \text { HADC2 } & \text { Histone deacetylase 2 } \\ \text { HDAC4 } & \text { Histone deacetylase } 4 \\ \text { HDL } & \text { High-density lipoprotein } \\ \text { HIF-1 } \alpha & \text { Hypoxia-inducible factor 1-alpha } \\ \text { HIF-2 } \alpha & \text { Hypoxia-inducible factor 2-alpha } \\ \text { IGFBP5 } & \text { Insulin-like growth factor-binding protein } 5 \\ & \end{array}$




\begin{tabular}{|c|c|}
\hline IGFIR & Insulin-like growth factor 1 receptor \\
\hline IGFR & Insulin-like growth factor 1 receptor \\
\hline IL & Interleukine \\
\hline iNOS & Inducible nitric oxide synthase \\
\hline InsR & Insulin receptor \\
\hline IRAK1 & Interleukin-1 receptor-associated kinase 1 \\
\hline LNA-ASO & Locked nucleic acid antisense oligonucleotide \\
\hline LncRNA H19 & Long non-coding RNA H19 \\
\hline MAP1LC3 & Microtubule-associated proteins 1A/1B light chain 3B \\
\hline miRNA & microRNA \\
\hline MMP-13 & Matrix metalloproteinase 13 \\
\hline MMP3 & Matrix metalloproteinase-3 \\
\hline NLRP3 & The Nacht, leucine-rich repeat and pyrin domain containing protein 3 \\
\hline NTXI & The cross-linked N-telopeptide of type I collagen \\
\hline $\mathrm{OA}$ & osteoarthritis \\
\hline $\mathrm{p} 16 \mathrm{INK} 4 \alpha$ & Cyclin dependent kinase inhibitor $2 \mathrm{~A}$ \\
\hline PARP p85 & Poly (ADP-ribose) polymerase p85 \\
\hline PI3K & Phosphoinositide 3-kinases \\
\hline PIIANP & N-propeptide of collagen IIA \\
\hline Ppp3r2 & Protein phosphatase 3 regulatory subunit B \\
\hline PTEN & Phosphatase and tensin homolog \\
\hline qPCR & Quantitative real-time PCR \\
\hline RALA & Ras-related protein Ral-A \\
\hline REG $\gamma$ & Langerhans regenerating protein $\gamma$ \\
\hline RUNX2 & Runt-related transcription factor 2 \\
\hline SHIP1 & Src homology 2 domain containing inositol polyphosphate 5-phosphatase 1 \\
\hline SIRT1 & Sirtuin 1 \\
\hline Smad2 & Mothers against decapentaplegic homolog 2 \\
\hline Smad3 & Mothers against decapentaplegic homolog 3 \\
\hline Smad4 & SMAD family member 4 \\
\hline SPP1 & Secreted phosphoprotein 1 \\
\hline TGF & Transforming growth factor \\
\hline TGIF2 & TGFB-induced factor homeobox 2 \\
\hline TIMP2 & Tissue inhibitor of metalloproteinases 2 \\
\hline TRAF3 & TNF receptor-associated factor 3 \\
\hline TRAF6 & TNF receptor associated factor 6 \\
\hline ULK1 & Unc-51-like autophagy activating kinase 1 \\
\hline VEGF & Vascular endothelial growth factor \\
\hline VEGFA & Vascular endothelial growth factor A \\
\hline WISP1 & Wnt1-inducible signaling pathway protein 1 \\
\hline
\end{tabular}

\section{References}

1. Beyer, C.; Zampetaki, A.; Lin, N.Y.; Kleyer, A.; Perricone, C.; Iagnocco, A.; Distler, A.; Langley, S.R.; Gelse, K.; Sesselmann, S.; et al. Signature of circulating microRNAs in osteoarthritis. Ann. Rheum. Dis. 2015, 74, e18. [CrossRef]

2. Chen, D.; Shen, J.; Zhao, W.; Wang, T.; Han, L.; Hamilton, J.L.; Im, H.J. Osteoarthritis: Toward a comprehensive understanding of pathological mechanism. Bone Res. 2017, 5, 16044. [CrossRef]

3. Panagopoulos, P.; Lambrou, G. The Involvement of MicroRNAs in Osteoarthritis and Recent Developments: A Narrative Review. Mediterr. J. Rheumatol. 2018, 29, 67-79. [CrossRef]

4. OECD. Health at a Glance 2019. In Health at a Glance; OECD: Paris, France, 2019; ISBN 9789264382084.

5. Reginster, J.Y. The prevalence and burden of arthritis. Rheumatology 2002, 41 (Suppl. S1), 3-6. [CrossRef] [PubMed]

6. $\quad$ Bitton, R. The economic burden of osteoarthritis. Am. J. Manag. Care 2009, 15, S230-S235. [PubMed]

7. Michael, J.W.P.; Schlüter-Brust, K.U.; Eysel, P. The Epidemiology, Etiology, Diagnosis, and Treatment of Osteoarthritis of the Knee. Dtsch. Aerzteblatt Online 2010, 107, 152-162. [CrossRef]

8. Kwoh, C.K. Epidemiology of osteoarthritis. Epidemiol. Aging 2012, 26, 523-536. [CrossRef]

9. Li, Q.; Amano, K.; Link, T.M.; Ma, C.B. Advanced Imaging in Osteoarthritis. Sports Health Multidiscip. Approach 2016, 8, 418-428. [CrossRef] [PubMed]

10. Litwic, A.; Edwards, M.H.; Dennison, E.M.; Cooper, C. Epidemiology and burden of osteoarthritis. Br. Med. Bull. 2013, 105, 185-199. [CrossRef] 
11. Driban, J.B.; Harkey, M.S.; Liu, S.H.; Salzler, M.; McAlindon, T.E. Osteoarthritis and Aging: Young Adults with Osteoarthritis. Curr. Epidemiol. Rep. 2020, 7, 9-15. [CrossRef]

12. Hame, S.L.; Alexander, R.A. Knee osteoarthritis in women. Curr. Rev. Musculoskelet. Med. 2013, 6, 182-187. [CrossRef] [PubMed]

13. Plotnikoff, R.; Karunamuni, N.; Lytvyak, E.; Penfold, C.; Schopflocher, D.; Imayama, I.; Johnson, S.T.; Raine, K. Osteoarthritis prevalence and modifiable factors: A population study. BMC Public Health 2015, 15, 1195. [CrossRef]

14. Vina, E.R.; Kwoh, C.K. Epidemiology of osteoarthritis: Literature update. Curr. Opin. Rheumatol. 2018, 30, 160-167. [CrossRef]

15. Fernández-Moreno, M.; Rego, I.; Carreira-Garcia, V.; Blanco, F.J. Genetics in osteoarthritis. Curr. Genom. 2008, 9, 542-547. [CrossRef] [PubMed]

16. Barter, M.J.; Bui, C.; Young, D.A. Epigenetic mechanisms in cartilage and osteoarthritis: DNA methylation, histone modifications and microRNAs. Osteoarthr. Cartil. 2012, 20, 339-349. [CrossRef]

17. Warner, S.C.; Valdes, A.M. Genetic association studies in osteoarthritis: Is it fairytale? Curr. Opin. Rheumatol. 2017, 29, 103-109. [CrossRef] [PubMed]

18. Fathollahi, A.; Aslani, S.; Jamshidi, A.; Mahmoudi, M. Epigenetics in osteoarthritis: Novel spotlight. J. Cell. Physiol. 2019, 234, 12309-12324. [CrossRef]

19. Thomas, A.C.; Hubbard-Turner, T.; Wikstrom, E.A.; Palmieri-Smith, R.M. Epidemiology of Posttraumatic Osteoarthritis. J. Athl. Train. 2017, 52, 491-496. [CrossRef] [PubMed]

20. Coggon, D.; Reading, I.; Croft, P.; McLaren, M.; Barrett, D.; Cooper, C. Knee osteoarthritis and obesity. Int. J. Obes. Relat. Metab. Disord. 2001, 25, 622-627. [CrossRef]

21. Dubé, C.E.; Liu, S.H.; Driban, J.B.; McAlindon, T.E.; Eaton, C.B.; Lapane, K.L. The relationship between smoking and knee osteoarthritis in the Osteoarthritis Initiative. Osteoarthr. Cartil. 2016, 24, 465-472. [CrossRef]

22. Kang, A.H.; Kim, M.R.; Shin, J.S.; Lee, J.; Lee, Y.J.; Park, Y.; Nam, D.; Kim, E.J.; Ha, I.H. Association between alcohol consumption and osteoarthritis prevalence in Korea as assessed by the alcohol use disorders identification test (AUDIT): A cross-sectional study. BMC Public Health 2020, 20, 227. [CrossRef] [PubMed]

23. Rayman, M.P. Diet, nutrition and osteoarthritis. BMC Musculoskelet Disord. 2015, 16, S7. [CrossRef]

24. Messina, O.D.; Vidal Wilman, M.; Vidal Neira, L.F. Nutrition, osteoarthritis and cartilage metabolism. Aging Clin. Exp. Res. 2019, 31, 807-813. [CrossRef]

25. Cooper, C.; Coggon, D. Physical activity and knee osteoarthritis. Lancet 1999, 353, 2177e8. [CrossRef]

26. Coggon, D.; Croft, P.; Kellingray, S.; Barrett, D.; McLaren, M.; Cooper, C. Occupational physical activities and osteoarthritis of the knee. Arthritis Rheum. 2000, 7, 1443-1449. [CrossRef] [PubMed]

27. Verbeek, J.; Mischke, C.; Robinson, R.; Ijaz, S.; Kuijer, P.; Kievit, A.; Ojajärvi, A.; Neuvonen, K. Occupational Exposure to Knee Loading and the Risk of Osteoarthritis of the Knee: A Systematic Review and a Dose-Response Meta-Analysis. Saf. Health Work 2017, 8, 130-142. [CrossRef] [PubMed]

28. McWilliams, D.F.; Leeb, B.F.; Muthuri, S.G.; Doherty, M.; Zhang, W. Occupational risk factors for osteoarthritis of the knee: A meta-analysis. Osteoarthr. Cartil. 2011, 19, 829-839. [CrossRef]

29. Yucesoy, B.; Charles, L.E.; Baker, B.; Burchfiel, C.M. Occupational and genetic risk factors for osteoarthritis: A review. Work 2015, 50, 261-273. [CrossRef]

30. Liem, Y.; Judge, A.; Kirwan, J.; Ourradi, K.; Li, Y.; Sharif, M. Multivariable logistic and linear regression models for identification of clinically useful biomarkers for osteoarthritis. Sci. Rep. 2020, 10, 11328. [CrossRef] [PubMed]

31. Denoble, A.E.; Huffman, K.M.; Stabler, T.V.; Kelly, S.J.; Hershfield, M.S.; McDaniel, G.E.; Coleman, R.E.; Kraus, V.B. Uric acid is a danger signal of increasing risk for osteoarthritis through inflammasome activation. Proc. Natl. Acad. Sci. USA 2011, 108, 2088-2093. [CrossRef] [PubMed]

32. Ishijima, M.; Kaneko, H.; Kaneko, K. The evolving role of biomarkers for osteoarthritis. Ther. Adv. Musculoskelet. Dis. 2014, 6 , 144-153. [CrossRef]

33. Hamilton, J.P. Epigenetics: Principles and Practice. Dig. Dis. 2011, 29, 130-135. [CrossRef]

34. Kung, L.H.W.; Zaki, S.; Ravi, V.; Rowley, L.; Smith, M.M.; Bell, K.M.; Bateman, J.F.; Little, C.B. Utility of circulating serum miRNAs as biomarkers of early cartilage degeneration in animal models of post-traumatic osteoarthritis and inflammatory arthritis. Osteoarthr. Cartil. 2017, 25, 426-434. [CrossRef]

35. O'Brien, J.; Hayder, H.; Zayed, Y.; Peng, C. Overview of MicroRNA Biogenesis, Mechanisms of Actions, and Circulation. Front. Endocrinol. 2018, 3, 402. [CrossRef]

36. Lao, T.D.; Le, T.A.H. MicroRNAs: Biogenesis, Functions and Potential Biomarkers for Early Screening, Prognosis and Therapeutic Molecular Monitoring of Nasopharyngeal Carcinoma. Processes 2020, 8, 966. [CrossRef]

37. Sohel, M.H. Extracellular/Circulating MicroRNAs: Release Mechanisms, Functions and Challenges. Achiev. Life Sci. 2016, 10, 175-186. [CrossRef]

38. Rapisuwon, S.; Vietsch, E.E.; Wellstein, A. Circulating biomarkers to monitor cancer progression and treatment. Comput. Struct. Biotechnol. J. 2016, 14, 211-222. [CrossRef] [PubMed]

39. Mi, S.; Zhang, J.; Zhang, W.; Huang, R.S. Circulating MicroRNAs as Biomarkers for Inflammatory Diseases. MicroRNA 2013, 2, 64-72. [CrossRef] [PubMed]

40. Min, P.K.; Chan, S.Y. The biology of circulating microRNAs in cardiovascular disease. Eur. J. Clin. Investig. 2015, 45, 860-874. [CrossRef] [PubMed] 
41. Duttagupta, R.; Jiang, R.; Gollub, J.; Getts, R.C.; Jones, K.W. Impact of Cellular miRNAs on Circulating miRNA Biomarker Signatures. PLOS ONE 2011, 6, e20769. [CrossRef]

42. Tahamtan, A.; Teymoori-Rad, M.; Nakstad, B.; Salimi, V. Anti-Inflammatory MicroRNAs and Their Potential for Inflammatory Diseases Treatment. Front. Immunol. 2018, 9, 1377. [CrossRef]

43. Thuy, L.H.A.; Thuan, L.D.; Phuong, T.K. DNA Hypermethylation in Breast Cancer. In Breast Cancer-From Biology to Medicine; InTech: London, UK, 2017.

44. Weng, L.; Wu, X.; Gao, H.; Mu, B.; Li, X.; Wang, J.H.; Guo, C.; Jin, J.M.; Chen, Z.; Covarrubias, M.; et al. MicroRNA profiling of clear cell renal cell carcinoma by whole-genome small RNA deep sequencing of paired frozen and formalin-fixed, paraffin-embedded tissue specimens. J. Pathol. 2010, 222, 41-51. [CrossRef]

45. Farazi, T.A.; Hoell, J.I.; Morozov, P.; Tuschl, T. MicroRNAs in human cancer. Adv. Exp. Med. Biol. 2013, 774, 1-20. [CrossRef] [PubMed]

46. Keller, A.; Leidinger, P.; Lange, J.; Borries, A.; Schroers, H.; Scheffler, M.; Lenhof, H.P.; Ruprecht, K.; Meese, E. Multiple sclerosis: microRNA expression profiles accurately differentiate patients with relapsing-remitting disease from healthy controls. PLoS ONE 2009, 13, e7440. [CrossRef] [PubMed]

47. Martins, M.; Rosa, A.; Guedes, L.C.; Fonseca, B.V.; Gotovac, K.; Violante, S.; Mestre, T.; Coelho, M.; Rosa, M.M.; Martin, E.R.; et al. Convergence of miRNA expression profiling, $\alpha$-synuclein interacton and GWAS in Parkinson's disease. PLoS ONE 2011, 6, e25443. [CrossRef] [PubMed]

48. Laczny, C.; Leidinger, P.; Haas, J.; Ludwig, N.; Backes, C.; Gerasch, A.; Kaufmann, M.; Vogel, B.; Katus, H.A.; Meder, B.; et al. miRTrail-A comprehensive webserver for analyzing gene and miRNA patterns to enhance the understanding of regulatory mechanisms in diseases. BMC Bioinform. 2012, 13, 36. [CrossRef] [PubMed]

49. Keller, A.; Leidinger, P.; Vogel, B.; Backes, C.; ElSharawy, A.; Galata, V.; Mueller, S.C.; Marquart, S.; Schrauder, M.G.; Strick, R.; et al miRNAs can be generally associated with human pathologies as exemplified for miR-144. BMC Med. 2014, 12, 224. [CrossRef] [PubMed]

50. Soyocak, A.; Kurt, H.; Ozgen, M.; Turgut Cosan, D.; Colak, E.; Gunes, H.V. miRNA-146a, miRNA-155 and JNK expression levels in peripheral blood mononuclear cells according to grade of knee osteoarthritis. Gene 2017, 627, 207-211. [CrossRef]

51. Okuhara, A.; Nakasa, T.; Shibuya, H.; Niimoto, T.; Adachi, N.; Deie, M.; Ochi, M. Changes in microRNA expression in peripheral mononuclear cells according to the progression of osteoarthritis. Mod. Rheumatol. 2012, 22, 446-457. [CrossRef]

52. Skrzypa, M.; Szala, D.; Gablo, N.; Czech, J.; Pajak, J.; Kopanska, M.; Trzeciak, M.; Gargasz, K.; Snela, S.; Zawlik, I. miRNA-146a-5p is upregulated in serum and cartilage samples of patients with osteoarthritis. Pol. Przegl. Chir. 2019, 91, 1-5. [CrossRef] [PubMed]

53. Rousseau, J.C.; Millet, M.; Croset, M.; Sornay-Rendu, E.; Borel, O.; Chapurlat, R. Association of circulating microRNAs with prevalent and incident knee osteoarthritis in women: The OFELY study. Arthritis Res. Ther. 2020, 22, 1-12. [CrossRef]

54. Cuadra, V.M.B.; González-Huerta, N.C.; Romero-Córdoba, S.; Hidalgo-Miranda, A.; Miranda-Duarte, A. Altered expression of circulating microRNA in plasma of patients with primary osteoarthritis and in silico analysis of their pathways. PLoS ONE 2014, 9, e97690. [CrossRef]

55. Li, Y.-H.; Tavallaee, G.; Tokar, T.; Nakamura, A.; Sundararajan, K.; Weston, A.; Sharma, A.; Mahomed, N.N.; Gandhi, R.; Jurisica, I.; et al. Identification of synovial fluid microRNA signature in knee osteoarthritis: Differentiating early- and late-stage knee osteoarthritis. Osteoarthr. Cartil. 2016, 24, 1577-1586. [CrossRef]

56. Ntoumou, E.; Tzetis, M.; Braoudaki, M.; Lambrou, G.; Poulou, M.; Malizos, K.; Stefanou, N.; Anastasopoulou, L.; Tsezou, A. Serum microRNA array analysis identifies miR-140-3p, miR-33b-3p and miR-671-3p as potential osteoarthritis biomarkers involved in metabolic processes. Clin. Epigenetics 2017, 9, 1-15. [CrossRef] [PubMed]

57. Murata, K.; Yoshitomi, H.; Tanida, S.; Ishikawa, M.; Nishitani, K.; Ito, H.; Nakamura, T. Plasma and synovial fluid microRNAs as potential biomarkers of rheumatoid arthritis and osteoarthritis. Arthritis Res. Ther. 2010, 12, R86. [CrossRef] [PubMed]

58. Kong, R.; Gao, J.; Si, Y.; Zhao, D. Combination of circulating miR-19b-3p, miR-122-5p and miR-486-5p expressions correlates with risk and disease severity of knee osteoarthritis. Am. J. Transl. Res. 2017, 9, 2852-2864. [PubMed]

59. Xie, W.; Su, W.; Xia, H.; Wang, Z.; Su, C.; Su, B. Synovial Fluid MicroRNA-210 as a Potential Biomarker for Early Prediction of Osteoarthritis. BioMed Res. Int. 2019, 2019, 1-4. [CrossRef] [PubMed]

60. Löfgren, S.E.; Frostegård, J.; Truedsson, L.; Pons-Estel, B.A.; D'Alfonso, S.; Witte, T.; Lauwerys, B.R.; Endreffy, E.; Kovács, L.; Vasconcelos, C.; et al. Genetic association of miRNA-146a with systemic lupus erythematosus in Europeans through decreased expression of the gene. Genes Immun. 2012, 13, 268-274. [CrossRef] [PubMed]

61. Luo, X.; Yang, W.; Ye, D.Q.; Cui, H.; Zhang, Y.; Hirankarn, N.; Qian, X.; Tang, Y.; Lau, Y.L.; de Vries, N.; et al. A functional variant in microRNA-146a promoter modulates its expression and confers disease risk for systemic lupus erythematosus. PLoS Genet. 2011, 7, e1002128. [CrossRef]

62. Sun, H.Y.; Lv, A.K.; Yao, H. Relationship of miRNA-146a to primary Sjögren's syndrome and to systemic lupus erythematosus: A meta-analysis. Rheumatol. Int. 2017, 37, 1311-1316. [CrossRef]

63. Li, J.; Yang, H.; Li, Y.; Liu, Y.; Chen, S.; Qi, C.; Zhang, Q.; Lan, T.; He, X.; Guan, X.Y.; et al. microRNA-146 up-regulation predicts the prognosis of non-small cell lung cancer by miRNA in situ hybridization. Exp. Mol. Pathol. 2014, 96, 195-199. [CrossRef]

64. Zhang, Z.; Zhang, Y.; Sun, X.X.; Ma, X.; Chen, Z.N. microRNA-146a inhibits cancer metastasis by downregulating VEGF through dual pathways in hepatocellular carcinoma. Mol. Cancer 2015, 14, 5. [CrossRef] 
65. Zhang, F.; Wang, J.; Chu, J.; Yang, C.; Xiao, H.; Zhao, C.; Sun, Z.; Gao, X.; Chen, G.; Han, Z.; et al. MicroRNA-146a Induced by Hypoxia Promotes Chondrocyte Autophagy through Bcl-2. Cell. Physiol. Biochem. 2015, 37, 1442-1453. [CrossRef]

66. Chen, G.; Gao, X.; Wang, J.; Yang, C.; Wang, Y.; Liu, Y.; Zou, W.; Liu, T. Hypoxia-induced microRNA-146a represses Bcl-2 through Traf6/IRAK1 but not Smad4 to promote chondrocyte autophagy. Biol. Chem. 2017, 398, 499-507. [CrossRef]

67. Jin, L.; Zhao, J.; Jing, W.; Yan, S.; Wang, X.; Xiao, C.; Ma, B. Role of miR-146a in human chondrocyte apoptosis in response to mechanical pressure injury in vitro. Int. J. Mol. Med. 2014, 34, 451-463. [CrossRef] [PubMed]

68. Houard, X.; Goldring, M.B.; Berenbaum, F. Homeostatic Mechanisms in Articular Cartilage and Role of Inflammation in Osteoarthritis. Curr. Rheumatol. Rep. 2013, 15, 375. [CrossRef]

69. Zhang, X.; Wang, C.; Zhao, J.; Xu, J.; Geng, Y.; Dai, L.; Huang, Y.; Fu, S.C.; Dai, K.; Zhang, X. MiR-146a facilitates osteoarthritis by regulating cartilage homeostasis via targeting Camk2d and Ppp3r2. Cell Death Dis. 2017, 8, 1-11. [CrossRef] [PubMed]

70. Lin, Z.; Tian, X.Y.; Huang, X.X.; He, L.L.; Xu, F. microRNA-186 inhibition of PI3K-AKT pathway via SPP1 inhibits chondrocyte apoptosis in mice with osteoarthritis. J. Cell. Physiol. 2019, 234, 6042-6053. [CrossRef] [PubMed]

71. Miyaki, S.; Nakasa, T.; Otsuki, S.; Grogan, S.P.; Higashiyama, R.; Inoue, A.; Kato, Y.; Sato, T.; Lotz, M.K.; Asahara, H. MicroRNA140 is expressed in differentiated human articular chondrocytes and modulates interleukin-1 responses. Arthritis Rheum. 2009, 60, 2723-2730. [CrossRef] [PubMed]

72. Liang, Z.; Zhuang, H.; Wang, G.; Li, Z.; Zhang, H.; Yu, T.; Zhang, B. MiRNA-140 is a negative feedback regulator of MMP-13 in IL-1 $\beta$-stimulated human articular chondrocyte C28/I2 cells. Inflamm. Res. 2012, 61, 503-509. [CrossRef]

73. Karlsen, T.A.; Jakobsen, R.B.; Mikkelsen, T.S.; Brinchmann, J.E. microRNA-140 Targets RALA and Regulates Chondrogenic Differentiation of Human Mesenchymal Stem Cells by Translational Enhancement of SOX9 and ACAN. Stem Cells Dev. 2014, 23, 290-304. [CrossRef] [PubMed]

74. Sondag, G.R.; Haqqi, T.M. The Role of MicroRNAs and Their Targets in Osteoarthritis. Curr. Rheumatol. Rep. 2016, 18, 56. [CrossRef]

75. Patra, D.; Sandell, L.J. Recent advances in biomarkers in osteoarthritis. Curr. Opin. Rheumatol. 2011, 23, 465-470. [CrossRef]

76. Kurowska-Stolarska, M.; Alivernini, S.; Ballantine, L.E.; Asquith, D.L.; Millar, N.L.; Gilchrist, D.S.; Reilly, J.; Ierna, M.; Fraser, A.R.; Stolarski, B.; et al. MicroRNA-155 as a proinflammatory regulator in clinical and experimental arthritis. Proc. Natl. Acad. Sci. USA 2011, 108, 11193-11198. [CrossRef] [PubMed]

77. Wu, X.-F.; Zhou, Z.-H.; Zou, J. MicroRNA-181 inhibits proliferation and promotes apoptosis of chondrocytes in osteoarthritis by targeting PTEN. Biochem. Cell Biol. 2017, 95, 437-444. [CrossRef]

78. Li, L.; Jia, J.; Liu, X.; Yang, S.; Ye, S.; Yang, W.; Zhang, Y. MicroRNA-16-5p Controls Development of Osteoarthritis by Targeting SMAD3 in Chondrocytes. Curr. Pharm. Des. 2015, 21, 5160-5167. [CrossRef] [PubMed]

79. Li, L.; Yang, C.; Liu, X.; Yang, S.; Ye, S.; Jia, J.; Liu, W.; Zhang, Y. Elevated expression of microRNA-30b in osteoarthritis and its role in ERG regulation of chondrocyte. Biomed. Pharmacother. 2015, 76, 94-99. [CrossRef] [PubMed]

80. Song, B.; Song, H.; Wang, W.; Wang, H.; Peng, H.; Cui, J.; Wang, R.; Huang, H.; Wang, W.; Wang, L. Beclin 1 overexpression inhibits chondrocyte apoptosis and downregulates extracellular matrix metabolism in osteoarthritis. Mol. Med. Rep. 2017, 16, 3958-3964. [CrossRef]

81. Yu, C.D.; Miao, W.H.; Zhang, Y.Y.; Zou, M.J.; Yan, X.F. Inhibition of miR-126 protects chondrocytes from IL-1 $\beta$ induced inflammation via upregulation of Bcl-2. Bone Jt. Res. 2018, 7, 414-421. [CrossRef] [PubMed]

82. Shu, Y.; Long, J.; Guo, W.; Ye, W. MicroRNA-195-5p inhibitor prevents the development of osteoarthritis by targeting REG $\gamma$. Mol. Med. Rep. 2019, 19, 4561-4568. [CrossRef]

83. Prasadam, I.; Xiao, Y. A microRNA screen reveals the critical role of microRNA-23a-3p in maintaining cartilage homeostasis. Osteoarthr. Cartil. 2018, 26, S160. [CrossRef]

84. Kang, L.; Yang, C.; Song, Y.; Liu, W.; Wang, K.; Li, S.; Zhang, Y. MicroRNA-23a-3p promotes the development of osteoarthritis by directly targeting SMAD3 in chondrocytes. Biochem. Biophys. Res. Commun. 2016, 478, 467-473. [CrossRef] [PubMed]

85. Philipot, D.; Guérit, D.; Platano, D.; Chuchana, P.; Olivotto, E.; Espinoza, F.; Dorandeu, A.; Pers, Y.M.; Piette, J.; Borzi, R.M.; et al. p16INK4a and its regulator miR-24 link senescence and chondrocyte terminal differentiation-associated matrix remodeling in osteoarthritis. Arthritis Res. Ther. 2014, 16, R58. [CrossRef] [PubMed]

86. Lv, S.; Xu, J.; Chen, L.; Wu, H.; Feng, W.; Zheng, Y.; Li, P.; Zhang, H.; Zhang, L.; Chi, G.; et al. MicroRNA-27b targets CBFB to inhibit differentiation of human bone marrow mesenchymal stem cells into hypertrophic chondrocytes. Stem Cell Res. Ther. 2020, 11, 392. [CrossRef] [PubMed]

87. Akhtar, N.; Rasheed, Z.; Ramamurthy, S.; Anbazhagan, A.N.; Voss, F.R.; Haqqi, T.M. MicroRNA-27b regulates the expression of matrix metalloproteinase 13 in human osteoarthritis chondrocytes. Arthritis Rheum. 2010, 62, 1361-1371. [CrossRef] [PubMed]

88. Abouheif, M.M.; Nakasa, T.; Shibuya, H.; Niimoto, T.; Kongcharoensombat, W.; Ochi, M. Silencing microRNA-34a inhibits chondrocyte apoptosis in a rat osteoarthritis model in vitro. Rheumatology 2010, 49, 2054-2060. [CrossRef]

89. Luo, C.; Liang, J.S.; Gong, J.; Zhang, H.L.; Feng, Z.J.; Yang, H.T.; Zhang, H.B.; Kong, Q.H. The function of microRNA-34a in osteoarthritis. Bratisl. Med. J. 2019, 120, 386-391. [CrossRef]

90. Mao, G.; Zhang, Z.; Huang, Z.; Chen, W.; Huang, G.; Meng, F.; Zhang, Z.; Kang, Y. MicroRNA-92a-3p regulates the expression of cartilage-specific genes by directly targeting histone deacetylase 2 in chondrogenesis and degradation. Osteoarthr. Cartil. 2017, 25, 521-532. [CrossRef] [PubMed] 
91. Xiaoling, G.; Shuaibin, L.; Kailu, L. MicroRNA-19b-3p promotes cell proliferation and osteogenic differentiation of BMSCs by interacting with lncRNA H19. BMC Med. Genet. 2020, 21, 11. [CrossRef] [PubMed]

92. Li, Y.; Yuan, F.; Song, Y.; Guan, X. miR-17-5p and miR-19b-3p prevent osteoarthritis progression by targeting EZH2. Exp. Ther. Med. 2020, 20, 1653-1663. [CrossRef] [PubMed]

93. Shi, J.; Guo, K.; Su, S.; Li, J.; Li, C. miR-486-5p is upregulated in osteoarthritis and inhibits chondrocyte proliferation and migration by suppressing SMAD2. Mol. Med. Rep. 2018, 18, 502-508. [CrossRef] [PubMed]

94. Kim, J.-H.; Kim, S.-J. Overexpression of MicroRNA-25 by Withaferin A Induces Cyclooxygenase-2 Expression in Rabbit Articular Chondrocytes. J. Pharmacol. Sci. 2014, 125, 83-90. [CrossRef] [PubMed]

95. Jones, S.W.; Watkins, G.; Le Good, N.; Roberts, S.; Murphy, C.L.; Brockbank, S.M.V.; Needham, M.R.C.; Read, S.J.; Newham, P. The identification of differentially expressed microRNA in osteoarthritic tissue that modulate the production of TNF- $\alpha$ and MMP13. Osteoarthr. Cartil. 2009, 17, 464-472. [CrossRef]

96. Zhao, X.; Li, H.; Wang, L. MicroRNA-107 regulates autophagy and apoptosis of osteoarthritis chondrocytes by targeting TRAF3. Int. Immunopharmacol. 2019, 71, 181-187. [CrossRef] [PubMed]

97. Walayat, A.; Yang, M.; Xiao, D. Therapeutic Implication of miRNA in Human Disease. In Antisense Therapy; IntechOpen: London, UK, 2019.

98. Oliviero, A.; Della Porta, G.; Peretti, G.M.; Maffulli, N. MicroRNA in osteoarthritis: Physiopathology, diagnosis and therapeutic challenge. Br. Med. Bull. 2019, 130, 137-147. [CrossRef] [PubMed]

99. Endisha, H.; Datta, P.; Sharma, A.; Nakamura, S.; Rossomacha, E.; Younan, C.; Ali, S.A.; Tavallaee, G.; Lively, S.; Potla, P.; et al. MicroRNA-34a-5p Promotes Joint Destruction during Osteoarthritis. Arthritis Rheumatol. 2020, 41552. [CrossRef]

100. Yan, S.; Wang, M.; Zhao, J.; Zhang, H.; Zhou, C.; Jin, L.; Zhang, Y.; Qiu, X.; Ma, B.; Fan, Q. MicroRNA-34a affects chondrocyte apoptosis and proliferation by targeting the SIRT1/p53 signaling pathway during the pathogenesis of osteoarthritis. Int. J. Mol. Med. 2016, 38, 201-209. [CrossRef]

101. Bai, Y.; Chen, K.; Zhan, J.; Wu, M. miR-122/SIRT1 axis regulates chondrocyte extracellular matrix degradation in osteoarthritis. Biosci. Rep. 2020, 40, 40. [CrossRef] [PubMed]

102. Li, W.; Cai, L.; Zhang, Y.; Cui, L.; Shen, G. Intra-articular resveratrol injection prevents osteoarthritis progression in a mouse model by activating SIRT1 and thereby silencing HIF-2 $\alpha$. J. Orthop. Res. 2015, 33, 1061-1070. [CrossRef] 